\title{
Synthesis of Gold Nanoparticles Using Whole Cells of Geotrichum candidum
}

\author{
Amit Kumar Mittal, Abhishek Kaler, Aparna Vasant Mulay, and Uttam Chand Banerjee \\ Department of Pharmaceutical Technology, National Institute of Pharmaceutical Education and Research, Sector-67, \\ SAS Nagar, Punjab 160062, India \\ Correspondence should be addressed to Uttam Chand Banerjee; ucbanerjee@niper.ac.in
}

Received 31 January 2013; Accepted 12 March 2013

Academic Editor: Hamed Bahmanpour

Copyright (C) 2013 Amit Kumar Mittal et al. This is an open access article distributed under the Creative Commons Attribution License, which permits unrestricted use, distribution, and reproduction in any medium, provided the original work is properly cited.

\begin{abstract}
The synthesis of nanoparticles with desired size and shape is an important area of research in nanotechnology. Use of biological system is an alternative approach to chemical and physical procedures for the synthesis of metal nanoparticles. An efficient environment-friendly approach for the biosynthesis of rapid and stable Gold nanoparticles (AuNPs) using whole cells of Geotrichum candidum is discussed in this paper. The enzymes/proteins present in the microorganism might be responsible for the reduction of metal salts to nanoparticles. Various reaction parameters such as culture age, temperature, $\mathrm{pH}$, metal salt, and cell mass concentrations were optimized. The AuNPs were characterized by UV-visible spectroscopy, dynamic light scattering (DLS), energy dispersive spectroscopy (EDS), scanning electron microscope (SEM), and Fourier transform infrared spectroscopy (FTIR). Nanoparticles were isolated by sonicating the whole cells after treatment with Tween 80 . The whole cell mediated process showed the simplistic, feasible, easy to scale up, and low-cost approach for the synthesis of AuNPs.
\end{abstract}

\section{Introduction}

Metal nanoparticles have been an extensive area of research because of their unique chemical, physical, and optical properties [1]. These make them potential candidates in the field of catalysis, labeling, biosensing, drug delivery, antimicrobial, and so forth $[2,3]$. AuNPs have wider ranges of applications in the biomedical field for biosensor development, drug delivery, imaging, photo diagnostics, and so forth [4]. Development of reliable processes for the synthesis of metal nanomaterials with excellent dispersity and stability with minimum harmful effects is the need of the day [5]. Traditional chemical and physical methods reported in the literature involve the use of hazardous chemicals and extreme reaction conditions [6-8]. The current research is directed towards the development of eco-friendly protocols for the synthesis of nanomaterials/nanostructures of desirable sizes and shapes $[9,10]$. Considering applications of AuNPs in the fields of biology and medicine, environment, and technology, there is a growing need for the development of cost-effective method for the synthesis of new nanoparticles
[11]. The biological methods fulfil all the requirements of a process to be green [12]. Synthesis of nanoparticles utilizing biological system such as bacteria, fungi, and several plant extracts have been widely reported in the literature $[6,13-$ 15]. Microorganisms are able to produce metal nanomaterials either intra- or extracellularly. Intracellular synthesis of metal nanoparticles (Pseudomonas stutzeri, Escherichia coli, Vibrio cholerae, Pseudomonas aeruginosa, Salmonells typlus, and Staphylococcus currens) has been investigated by many workers $[16,17]$. The formation of extracellular silver nanoparticles by photoautotrophic cyanobacteria, Plectonema boryanum, has been described in [18]. The intracellular synthesis of AuNPs by microbial reduction of $\mathrm{Au}^{+3}$ using Shewanella algae has been investigated by Konishi et al. in 2006 and Konishi et al. in 2007 [19, 20]. The synthesis of AuNPs of different sizes and shapes has been reported in both aqueous and nonpolar organic solvents [21, 22]. Some well-known examples of plant mediated synthesis of gold nanotriangles using aloe-vera extract and tamarind leaf extract are also available in literature $[23,24]$. In this paper, we report the intracellular synthesis of AuNPs using 
yeast, Geotrichum candidum, its downstream processing and characterization.

\section{Materials and Methods}

2.1. Chemicals. Gold (III) chloride trihydrate salt (99.99\%) was purchased from Sigma-Aldrich (Steinheim, Germany). Different salts, buffer, and media components were purchased from Qualigens Chemicals (Mumbai, India), Hi Media (Mumbai, India), and Central Drug House (P) (New Delhi, India).

2.2. Microorganism and Culture Conditions. Geotrichum candidum NCIM 980 was procured from National Collection of Industrial Microorganisms, National Chemical Laboratory, Pune, India. The organism was grown in YPD medium (yeast extract $3 \mathrm{~g} / \mathrm{L}$, peptone $3 \mathrm{~g} / \mathrm{L}$ and dextrose $10 \mathrm{~g} / \mathrm{L}, \mathrm{pH} 6.5$ ) at $30^{\circ} \mathrm{C}$ in an incubator shaker (200 rpm).

2.3. Synthesis of Gold Nanoparticle and Its Downstream Processing. The cells were grown in specified medium for $24 \mathrm{~h}$ at $30^{\circ} \mathrm{C}$ in shaker incubator $(200 \mathrm{rpm})$. The fermentation broth was centrifuged at $7,000 \times \mathrm{g}$ for $15 \mathrm{~min}$; cells were washed thoroughly and resuspended in deionised water. Suspension of wet cell mass (10\%) in deionised water was prepared. Tetrachloroauric acid trihydrate $\left(\mathrm{AuCl}_{4} \cdot 3 \mathrm{H}_{2} \mathrm{O}\right)$ was added to the cell suspension (10\%) to final concentration of $1 \mathrm{mM}$. The reaction was carried out at $30^{\circ} \mathrm{C}, 200 \mathrm{rpm}$ for $72 \mathrm{~h}$ and observed for visual colour change. For the isolation of nanoparticles from the whole cells, various disruption methods were used. Cell disruption was performed using ultrasonication after treatment with surfactant (Tween $80)$. The supernatant was collected after centrifugation at $10,000 \times \mathrm{g}$ for $15 \mathrm{~min}$ and lyophilized to concentrate the AuNPs.

2.4. Characterization of Nanoparticles. An essential part in the synthesis of nanoparticles is its characterization. The synthesised AuNPs were characterized by UV-visible spectrometry, dynamic light scattering (DLS), scanning electron microscopy (SEM), Fourier transform infrared spectroscopy (FTIR), and energy dispersive spectroscopy (EDS). Observation of strong broad surface plasmon peaks at visible regions (510-525 nm) has been well documented for AuNPs, with sizes ranging widely from 10 to $100 \mathrm{~nm}$. The reduction of pure $\mathrm{Au}^{+3}$ ions to $\mathrm{Au}^{\mathrm{o}}$ was monitored by measuring through UVVis spectroscopy by taking the samples of reaction mixture (gold nanoparticle solution). Dynamic light scattering (DLS or Zeta-sizer) was used to measure the size, size distribution, and potential (charge) of nanoparticles dispersed in a liquid. Scanning electron microscopic (SEM) analysis was done using the instrument (S-3400, Hitachi) operated at an excitation voltage of $25 \mathrm{kV}$. The nanoparticles or whole cell suspensions were mounted onto steel stage using doublesided adhesive tape on a glass cover slip by just dropping a very small amount of the sample on the cover slip, and the film was allowed to dry and coated with gold using ion sputter (E-1010, Hitachi). The SEM was used for the determination of size and morphology of the nanoparticles. The functional groups and capping of the synthesized AuNPs were confirmed by FTIR spectroscopy. Elemental analysis and chemical composition of NPs were determined using energy dispersive spectroscopy.

\subsection{Optimization of Various Reaction Parameters}

2.5.1. Culture Age and Its Concentration. Cell age has pronounced effect on the synthesis of nanoparticles. In order to determine the optimum culture cell age for nanoparticle production, the cells were harvested at different phases of growth. After harvesting, the cells were thoroughly washed, resuspended in deionised water, and tetrachloroauric acid trihydrate $\left(\mathrm{AuCl}_{4} \cdot 3 \mathrm{H}_{2} \mathrm{O}\right)$ was added to make final concentration of $1 \mathrm{mM}$, and reaction mixture was incubated at $30^{\circ} \mathrm{C}$ $(200 \mathrm{rpm})$. After $48 \mathrm{~h}$, cells were harvested by centrifugation at $7,000 \times \mathrm{g}$ for $15 \mathrm{~min}$. The effect of cell mass concentration was studied by incubating different concentrations of cells $(25-250 \mathrm{mg} / \mathrm{mL})$ with gold salt at $35^{\circ} \mathrm{C}(200 \mathrm{rpm})$ for $72 \mathrm{~h}$. From time to time, the samples were taken from the reaction mixture, and nanoparticles were characterized according to the set procedures.

2.5.2. Reaction Temperature. Tetrachloroauric acid trihydrate $\left(\mathrm{AuCl}_{4} \cdot 3 \mathrm{H}_{2} \mathrm{O}\right)$ was added in $1 \mathrm{mM}$ concentration to the resuspended whole cells, and the flasks were incubated at a range of temperature of 15 to $40^{\circ} \mathrm{C}(200 \mathrm{rpm})$. Samples were collected at a regular interval of time and characterized accordingly.

2.5.3. Reaction $p H$. To the cell suspension, tetrachloroauric acid trihydrate $\left(\mathrm{AuCl}_{4} \cdot 3 \mathrm{H}_{2} \mathrm{O}\right)$ was added to achieve a final concentration of $1 \mathrm{mM}$, and the flasks were incubated at $35^{\circ} \mathrm{C}$ $(200 \mathrm{rpm})$. A range of $\mathrm{pH}(3-13)$ of the reaction mixture was chosen. Samples were collected at a regular interval of time and characterized accordingly.

2.5.4. Metal Salts. To the whole cell suspension, different concentrations ( 1 to $10 \mathrm{mM}$ ) of $\mathrm{AuCl}_{4} \cdot 3 \mathrm{H}_{2} \mathrm{O}$ were added, and the flasks were incubated at $35^{\circ} \mathrm{C}(200 \mathrm{rpm})$. Samples were collected at a regular interval of time and characterized accordingly.

\section{Results and Discussion}

The shape, size, and size distribution of metal nanoparticles produced by the reduction of gold ion $\left(\mathrm{Au}^{3+}\right)$ by Geotrichum candidum in solution depend on various reaction conditions such as temperature, cell age, cell mass $\mathrm{pH}$, and concentration of metal salt. After downstream processing, the nanoparticles were characterized by various techniques.

\subsection{Characterization of AuNPs}

3.1.1. Visual Observation. It has been reported [25] in the literature that the formation of AuNPs is detected by observing 


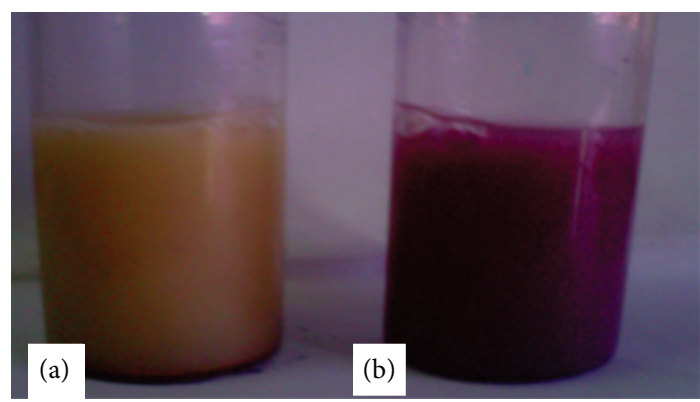

FIGURE 1: Visual observations of AuNPs produced by whole cell Geotrichum candidum.

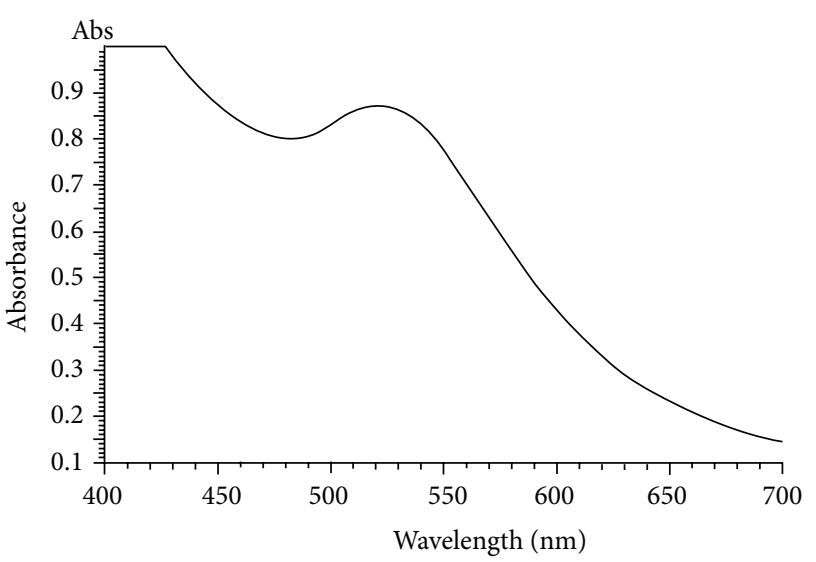

FIgURE 2: UV-Vis spectra of AuNPs produced by whole cell Geotrichum candidum.

the colour change of reaction mixture. In this case, also the formation of nanoparticle was preliminarily identified by observing the colour change of the reaction mixture (Figure 1). The cell mass of G. candidum turned light yellow (Figure 1(a)) to purple colour (Figure 1(b)) indicating the synthesis of AuNPs. The synthesis might be either intracellular or on the cell surface.

3.1.2. UV-Vis Spectral Analysis. As previously reported by other workers [26] on the colloidal solution of gold nanoparticle when subjected to UV-Vis spectrometry, a strong peak was absorbed at $520-530 \mathrm{~nm}$ (Figure 2).

3.1.3. Control of Size and Shape of AuNPs. To achieve the better size and shape of AuNPs synthesised by the cells of Geotrichum candidum, parameters such as cell age, $\mathrm{pH}$, temperature, metal ion, and cell mass concentration were optimized. Metabolic activities of cell vary with the cell age. The cellmass harvested at $48 \mathrm{~h}$ of growth produced highest amount of AuNPs (Figure 3(a)). This may be due to expression of higher amount of reductant at that the time of harvest ( $48 \mathrm{~h}$ growth) resulting in higher reduction. With the increase in temperature, reaction rate increased up to a certain value and then it started decreasing. Temperature of $35^{\circ} \mathrm{C}$ was found to be optimum for nanoparticle synthesis, beyond which the absorption at $520 \mathrm{~nm}$ decreased (Figure 3(b)). This may be due to instability of reductive compounds (protein/peptide) at higher temperatures. Gericke and Pinches [27] also found similar effect for the Aunanoparticle synthesis. Nanoparticle synthesis is a crystallisation phenomenon that depends upon solubility of salt in the media. $\mathrm{pH}$ affects the solubility and thus can affect the nanoparticle formation. The optimum $\mathrm{pH}$ for synthesis of gold nanoparticle was found to be 7 where the maximum absorption was observed (Figure 3(c)). Both above and below $\mathrm{pH} 7$, aggregation took place. Higher concentration of auric chloride was found to be toxic to the microbial cell. Lower concentration of auric chloride $(1 \mathrm{mM})$ was very efficiently reduced by the cells of G. candidum (Figure 3(d)). Cellmass concentration also showed prominent effect on the nanoparticle formation. Keeping all the other parameters constant, the cellmass concentration was varied from 25 to $250 \mathrm{mg} / \mathrm{mL}$, and $50 \mathrm{mg} / \mathrm{mL}$ was found to give maximum yield of AuNPs (Figure 3(e)).

3.1.4. Zetasizer. The synthesized nanoparticles have average particle size of about $76.58 \mathrm{~nm}$ and PDI of 0.231 (Figure 4(a)) which indicates monodispersity, and Zeta potential of $-17.5 \mathrm{mV}$ (Figure 4(b)) shows that the synthesized AuNPs are capped by -vely charged groups and are moderately stable.

3.1.5. Scanning Electron Microscopy (SEM) Analysis. A representative SEM image of the synthesized AuNPs is shown in Figure 5. This SEM image shows that the synthesized nanoparticles lay on the surface of Geotrichum candidum (Figure 5(a)). The average nanoparticle size lies in the range of 65-70 nm. Figure 5(b) shows the harvested AuNPs isolated from the cellmass of G. candidum.

3.1.6. Energy Dispersive Spectroscopy (EDS). An area profile EDS spectra of AuNPs (Figure 6) synthesized by whole cells of $G$. candidum after purification showed the presence of strong signals of the gold atoms.

3.1.7. FTIR Spectroscopy. FTIR spectroscopy analysis was done to reveal the involvement of possible biomolecules affecting the reduction and subsequent capping of the metal nanoparticles [28] synthesized by G. candidum. The proteins can bind to nanoparticles through its various functional groups [29]. The FTIR spectra revealed the presence of different functional groups such as amide and $-\mathrm{COOH}$ linkages on amino acid residues in protein and synthesized AuNPs. The bands were observed at $1299 \mathrm{~cm}^{-1}, 3433.14 \mathrm{~cm}^{-1}$, $2923.27 \mathrm{~cm}^{-1}$, and $1735.66 \mathrm{~cm}^{-1}$ (Figure 7), acknowledged as amide III band, $-\mathrm{OH}$ stretching, $\mathrm{C}-\mathrm{H}$ stretching, and $\mathrm{C}-$ $\mathrm{O}$ stretching of carboxylic acid, respectively [30]. The band at $1647 \mathrm{~cm}^{-1}$ represents $\mathrm{C}=\mathrm{O}$ stretching of amide bond. The band at $1351.71 \mathrm{~cm}^{-1}$ represents $\mathrm{C}-\mathrm{N}$ stretching which is commonly present in proteins, indicating the presence of protein as ligand for AuNPs, which increases the stability 


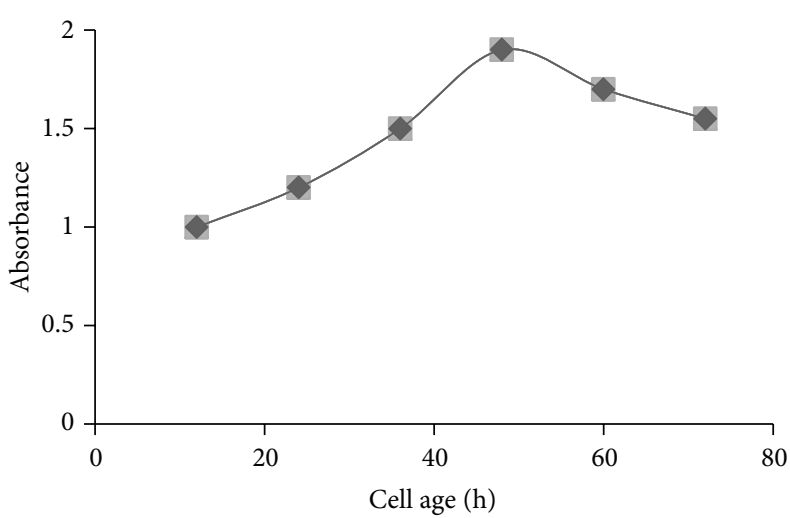

(a)

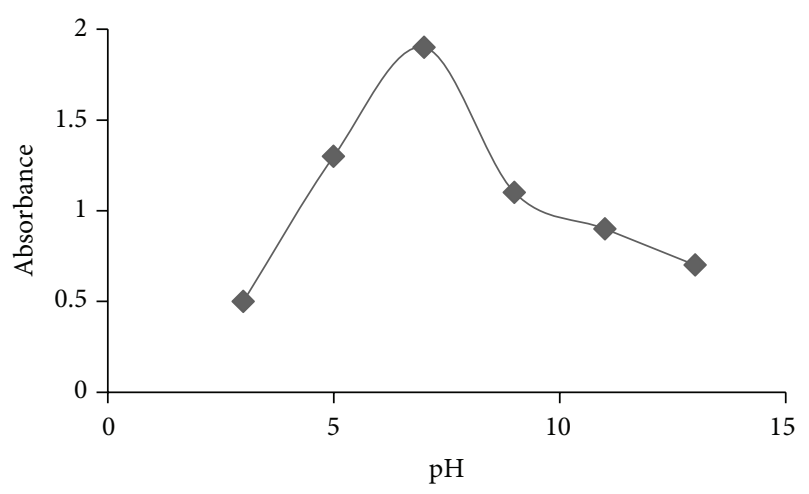

(c)



(b)



(d)

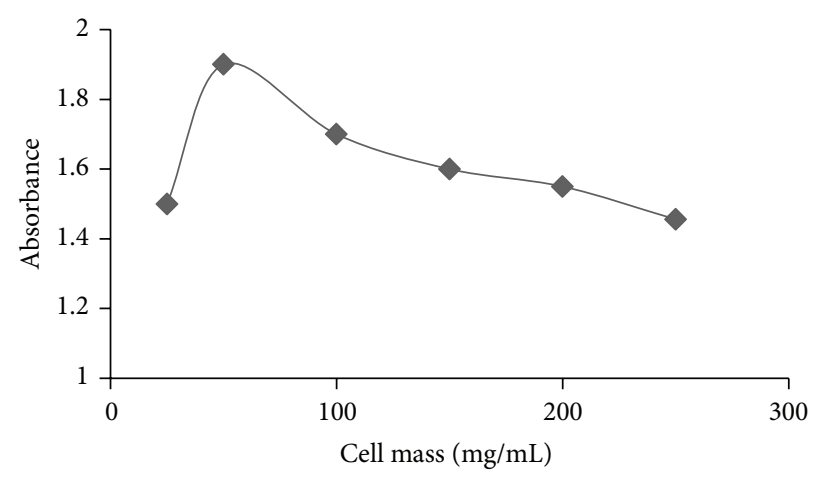

(e)

FIGURE 3: Optimization of various physicochemical parameters for AuNPs synthesis by whole cells of Geotrichum candidum.

of synthesized nanoparticles [31]. All peaks of FTIR spectra showed the presence of protein attachment to the AuNPs.

\section{Conclusion}

Geotrichum candidum was reported for the first time to synthesize AuNPs. Various reaction parameters like cell age, temperature, $\mathrm{pH}$, cell mass, and metal ion concentration, were optimized to increase the yield and to improve the dispersity of nanoparticles. Proteins are responsible for the reduction of metal salts as well as its stabilization by capping. The gold nanoparticle throughout the cellmass suggests that
$\mathrm{Au}^{+3}$ ions entered the cells through a transport system. The presence of different metabolic enzymes inside the cells or cytoplasm probably reduced $\mathrm{Au}^{+3}$ to $\mathrm{Au}^{\circ}$ and capped it by protective peptide/proteins. The microorganism mediated synthesis of metal nanoparticles can be a viable alternative to physical and chemical methods and can be easily scaled up.

\section{Conflict of Interests}

All the authors have no conflict of interests relevant to this paper. 


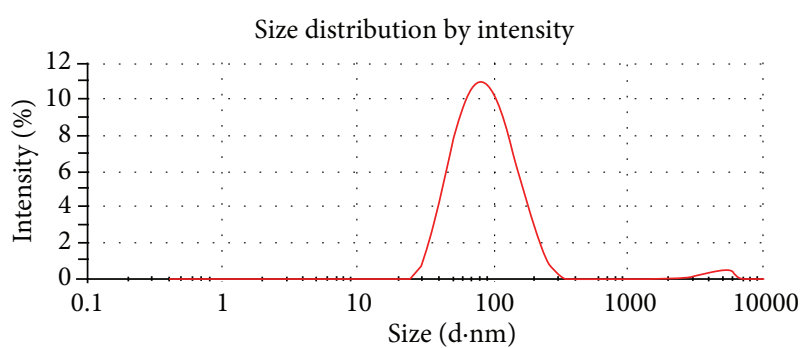

(a)

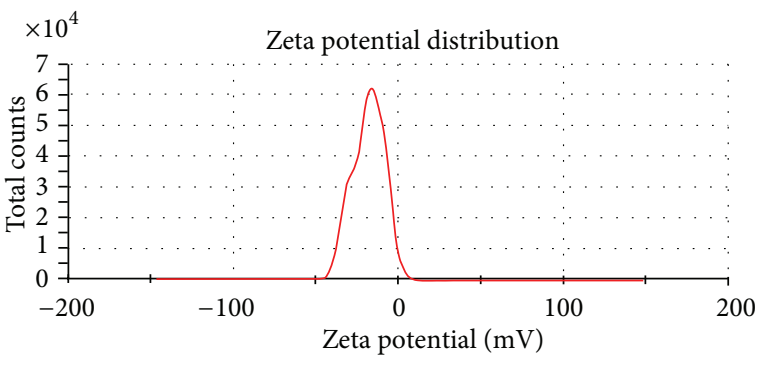

(b)

Figure 4: (a) Zetasizer distribution and (b) Zeta potential of AuNPs synthesized by whole cell of Geotrichum candidum.

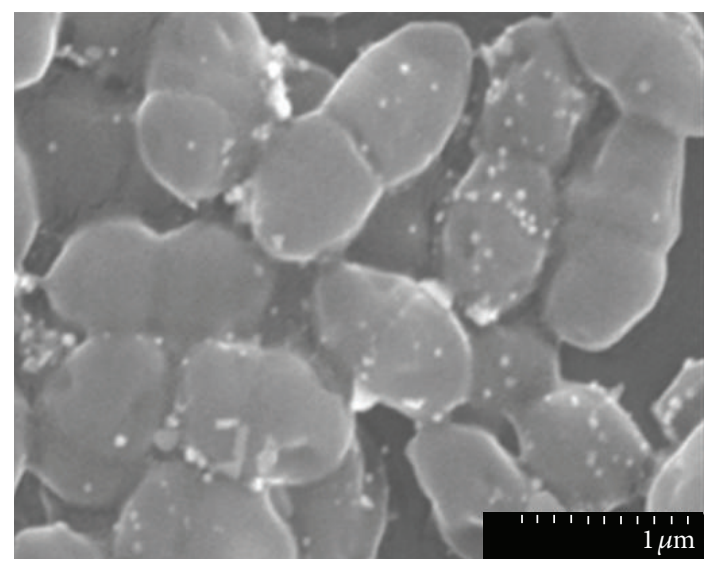

(a)

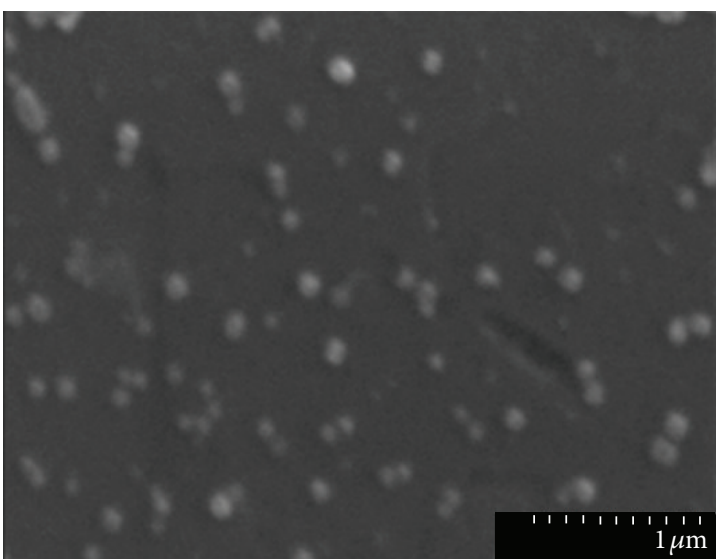

(b)

FIGURE 5: SEM images of AuNPs synthesized by Geotrichum candidum (a) in the whole cell and (b) after downstream processing.

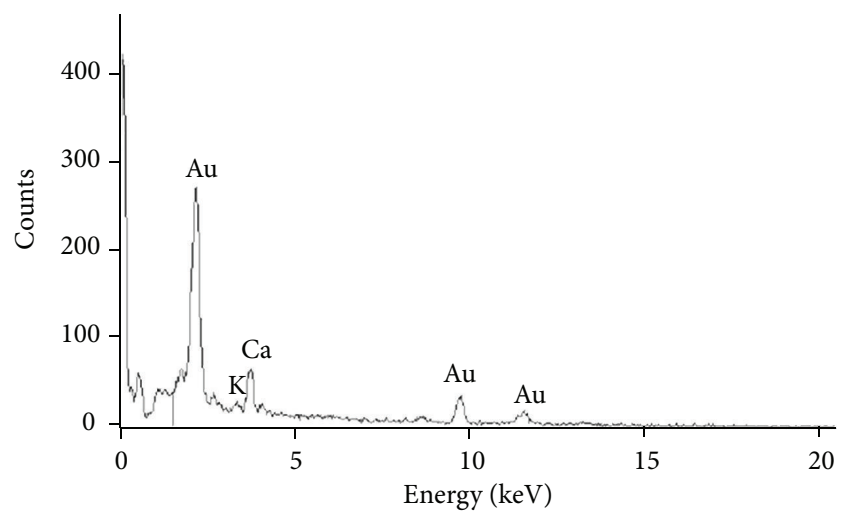

FIGURE 6: EDS spectra of AuNPs synthesized by whole cells G. candidum.

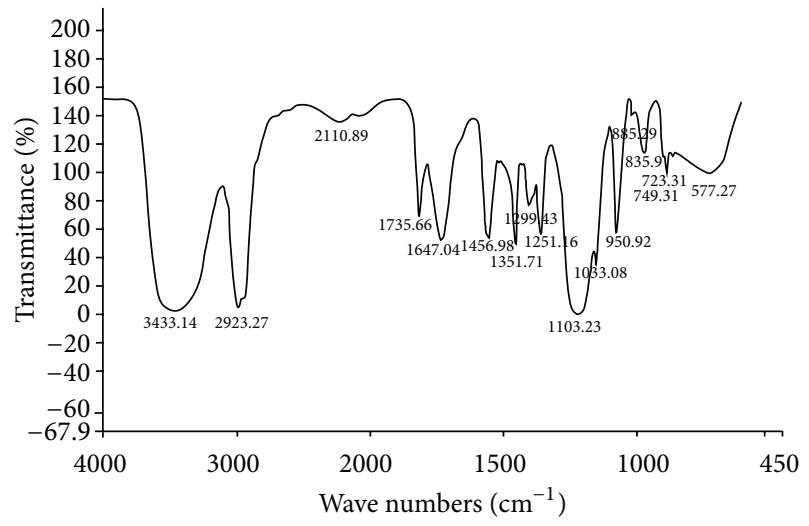

FIGURE 7: FTIR spectra of AuNPs synthesized by whole cell Geotrichum candidum NCIM 980 after harvesting.

\section{Acknowledgments}

One of the authors (A. K. Mittal) gratefully acknowledges financial support from the CSIR, and both A. Kaler and A. V. Mulay gratefully acknowledge the financial support from DBT, New Delhi, India.

\section{References}

[1] P. K. Jain, X. Huang, I. H. El-Sayed, and M. A. El-Sayed, "Noble metals on the nanoscale: optical and photothermal properties and some applications in imaging, sensing, biology, and medicine," Accounts of Chemical Research, vol. 41, no. 12, pp. 1578-1586, 2008.

[2] F. S. Rosarin and S. Mirunalini, "Nobel metallic nanoparticles with novel biomedical properties," Journal of Bioanalysis \& Biomedicine, vol. 3, pp. 085-091, 2011.

[3] M. Solomon and G. G. M. D'Souza, "Recent progress in the therapeutic applications of nanotechnology," Current Opinion in Pediatrics, vol. 23, no. 2, pp. 215-220, 2011.

[4] E. Boisselier and D. Astruc, "Gold nanoparticles in nanomedicine: preparations, imaging, diagnostics, therapies and toxicity," Chemical Society Reviews, vol. 38, no. 6, pp. 1759-1782, 2009. 
[5] J. A. Dahl, B. L. S. Maddux, and J. E. Hutchison, "Toward greener nanosynthesis," Chemical Reviews, vol. 107, no. 6, pp. 2228-2269, 2007.

[6] K. N. Thakkar, S. S. Mhatre, and R. Y. Parikh, "Biological synthesis of metallic nanoparticles," Nanomedicine, vol. 6, no. 2, pp. 257-262, 2010.

[7] R. Sanghi and P. Verma, "15 Microbes as green and ecofriendly nanofactories," in Green Chemistry for Environmental Sustainability, S. K. Sharma, Ed., p. 315, CRC Press, 2010.

[8] H. Korbekandi, S. Iravani, and S. Abbasi, "Production of nanoparticles using organisms Production of nanoparticles using organisms," Critical Reviews in Biotechnology, vol. 29, no. 4, pp. 279-306, 2009.

[9] A. Ahmad, P. Mukherjee, S. Senapati et al., "Extracellular biosynthesis of silver nanoparticles using the fungus Fusarium oxysporum," Colloids and Surfaces B, vol. 28, no. 4, pp. 313-318, 2003.

[10] A. K. Gade, P. Bonde, A. P. Ingle, P. D. Marcato, N. Durán, and M. K. Rai, "Exploitation of Aspergillus niger for synthesis of silver nanoparticles," Journal of Biobased Materials and Bioenergy, vol. 2, no. 3, pp. 243-247, 2008.

[11] L. Dykman and K. Nikolai, "AuNPs in biomedical applications: recent advances and perspectives," Chemical Society Reviews, vol. 41, no. 6, pp. 2256-2282, 2012.

[12] S. Marimuthu, A. A. Rahuman, G. Rajakumar et al., "Evaluation of green synthesized silver nanoparticles against parasites," Parasitology Research, vol. 108, no. 6, pp. 1541-1549, 2011.

[13] A. K. Mittal, Y. Chisti, and U. C. Banerjee, "Synthesis of metallic nanoparticles using plant extracts," Biotechnology Advances, vol. 31, no. 2, pp. 346-356, 2013.

[14] A. K. Mittal, A. Kaler, and U. C. Banerjee, "Free radical scavenging and antioxidant activity of silver nanoparticles synthesized from flower extract of Rhododendron dauricum," Nano Biomedicine and Engineering, vol. 4, no. 3, pp. 118-124, 2012.

[15] K. B. Narayanan and N. Sakthivel, "Biological synthesis of metal nanoparticles by microbes," Advances in Colloid and Interface Science, vol. 156, no. 1-2, pp. 1-13, 2010.

[16] Z. Sadowski, "Biosynthesis and application of silver and AuNPs," Wroclaw University of Technology, p. 257, 2009.

[17] A. Kaler, R. Nankar, M. S. Bhattacharyya, and U. C. Banerjee, "Extracellular biosynthesis of silver nanoparticles using aqueous extract of Candida viswanathii," Journal of Bionanoscience, vol. 5, no. 1, pp. 53-58, 2011.

[18] M. F. Lengke, M. E. Fleet, and G. Southam, "Biosynthesis of silver nanoparticles by filamentous cyanobacteria from a silver(I) nitrate complex," Langmuir, vol. 23, no. 5, pp. 26942699, 2007.

[19] Y. Konishi, T. Tsukiyama, K. Ohno, N. Saitoh, T. Nomura, and S. Nagamine, "Intracellular recovery of gold by microbial reduction of $\mathrm{AuCl}^{4}$ - ions using the anaerobic bacterium Shewanella algae," Hydrometallurgy, vol. 81, no. 1, pp. 24-29, 2006.

[20] Y. Konishi, K. Ohno, N. Saitoh et al., "Bioreductive deposition of platinum nanoparticles on the bacterium Shewanella algae," Journal of Biotechnology, vol. 128, no. 3, pp. 648-653, 2007.

[21] P. R. Selvakannan, S. Mandal, R. Pasricha, S. D. Adyanthaya, and M. Sastry, "One-step synthesis of hydrophobized gold nanoparticles of controllable size by the reduction of aqueous chloroaurate ions by hexadecylaniline at the liquid-liquid interface," Chemical Communications, no. 13, pp. 1334-1335, 2002.
[22] T. K. Sau and C. J. Murphy, "Room temperature, high-yield synthesis of multiple shapes of gold nanoparticles in aqueous solution," Journal of the American Chemical Society, vol. 126, no. 28, pp. 8648-8649, 2004.

[23] S. P. Chandran, M. Chaudhary, R. Pasricha, A. Ahmad, and M. Sastry, "Synthesis of gold nanotriangles and silver nanoparticles using Aloe vera plant extract," Biotechnology Progress, vol. 22, no. 2, pp. 577-583, 2006.

[24] B. Ankamwar, M. Chaudhary, and M. Sastry, "Gold nanotriangles biologically synthesized using tamarind leaf extract and potential application in vapor sensing," Synthesis and Reactivity in Inorganic, Metal-Organic and Nano-Metal Chemistry, vol. 35, no. 1, pp. 19-26, 2005.

[25] P. Mukherjee, S. Senapati, D. Mandal et al., "Extracellular synthesis of AuNPs by the fungus Fusarium oxysporum," ChemBioChem, vol. 3, no. 5, pp. 461-463, 2002.

[26] S. S. Shankar, A. Rai, A. Ahmad, and M. Sastry, "Rapid synthesis of $\mathrm{Au}, \mathrm{Ag}$, and bimetallic Au core-Ag shell nanoparticles using Neem (Azadirachta indica) leaf broth," Journal of Colloid and Interface Science, vol. 275, no. 2, pp. 496-502, 2004.

[27] M. Gericke and A. Pinches, "Biological synthesis of metal nanoparticles," Hydrometallurgy, vol. 83, no. 1-4, pp. 132-140, 2006.

[28] S. S. Shankar, A. Ahmad, and M. Sastry, "Geranium leaf assisted biosynthesis of silver nanoparticles," Biotechnology Progress, vol. 19, no. 6, pp. 1627-1631, 2003.

[29] C. M. Niemeyer, "Nanoparticles, proteins, and nucleic acids: biotechnology meets materials science," Angewandte Chemie International Edition, vol. 40, no. 22, pp. 4129-4158, 2001.

[30] B. D. Chithrani, A. A. Ghazani, and W. C. W. Chan, "Determining the size and shape dependence of gold nanoparticle uptake into mammalian cells," Nano Letters, vol. 6, no. 4, pp. 662-668, 2006.

[31] N. Vigneshwaran, N. M. Ashtaputre, P. V. Varadarajan, R. P. Nachane, K. M. Paralikar, and R. H. Balasubramanya, "Biological synthesis of silver nanoparticles using the fungus Aspergillus flavus," Materials Letters, vol. 61, no. 6, pp. 1413-1418, 2007. 

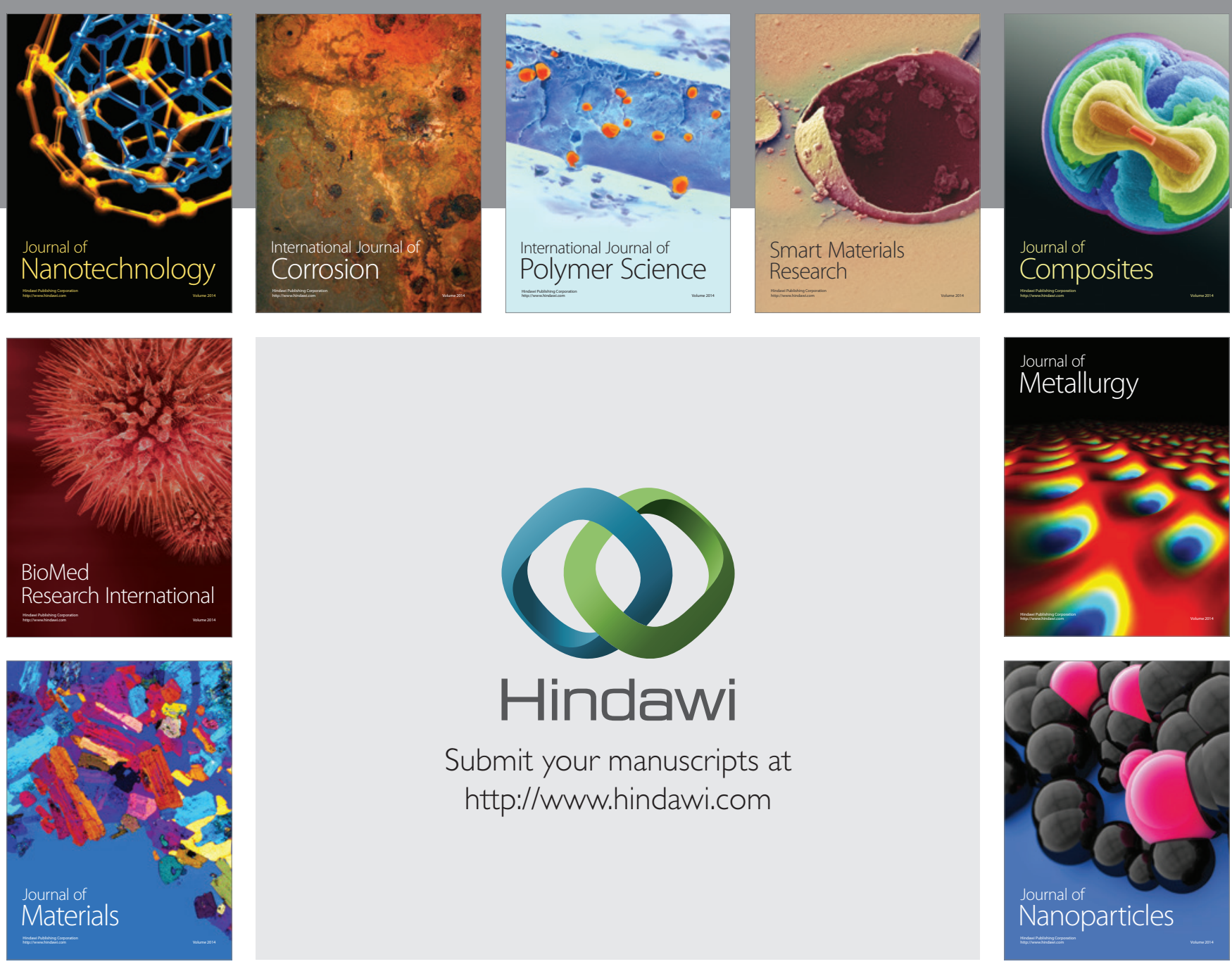

Submit your manuscripts at http://www.hindawi.com
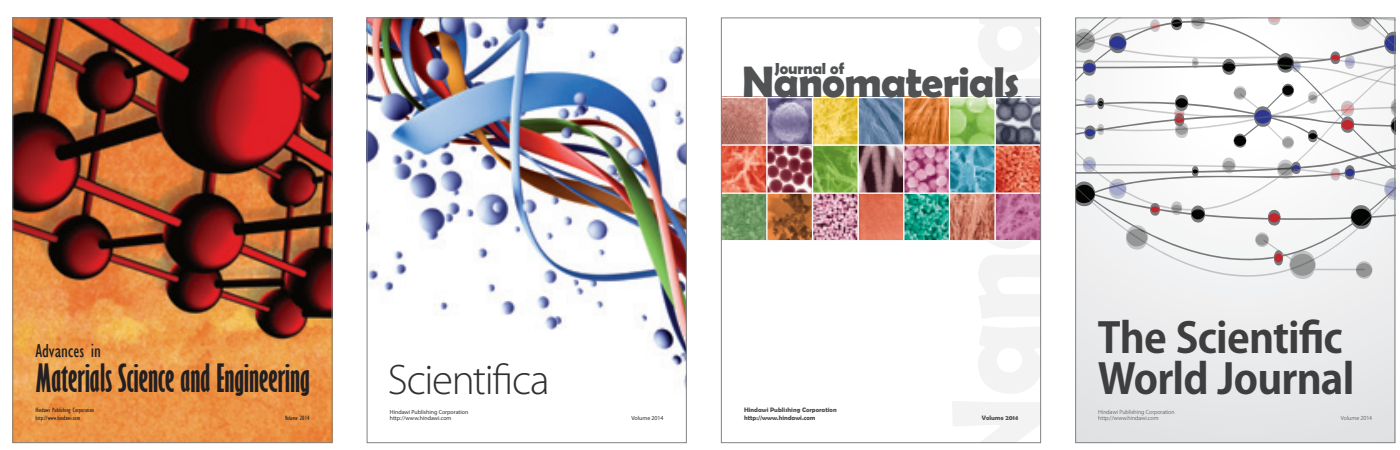

\section{The Scientific World Journal}
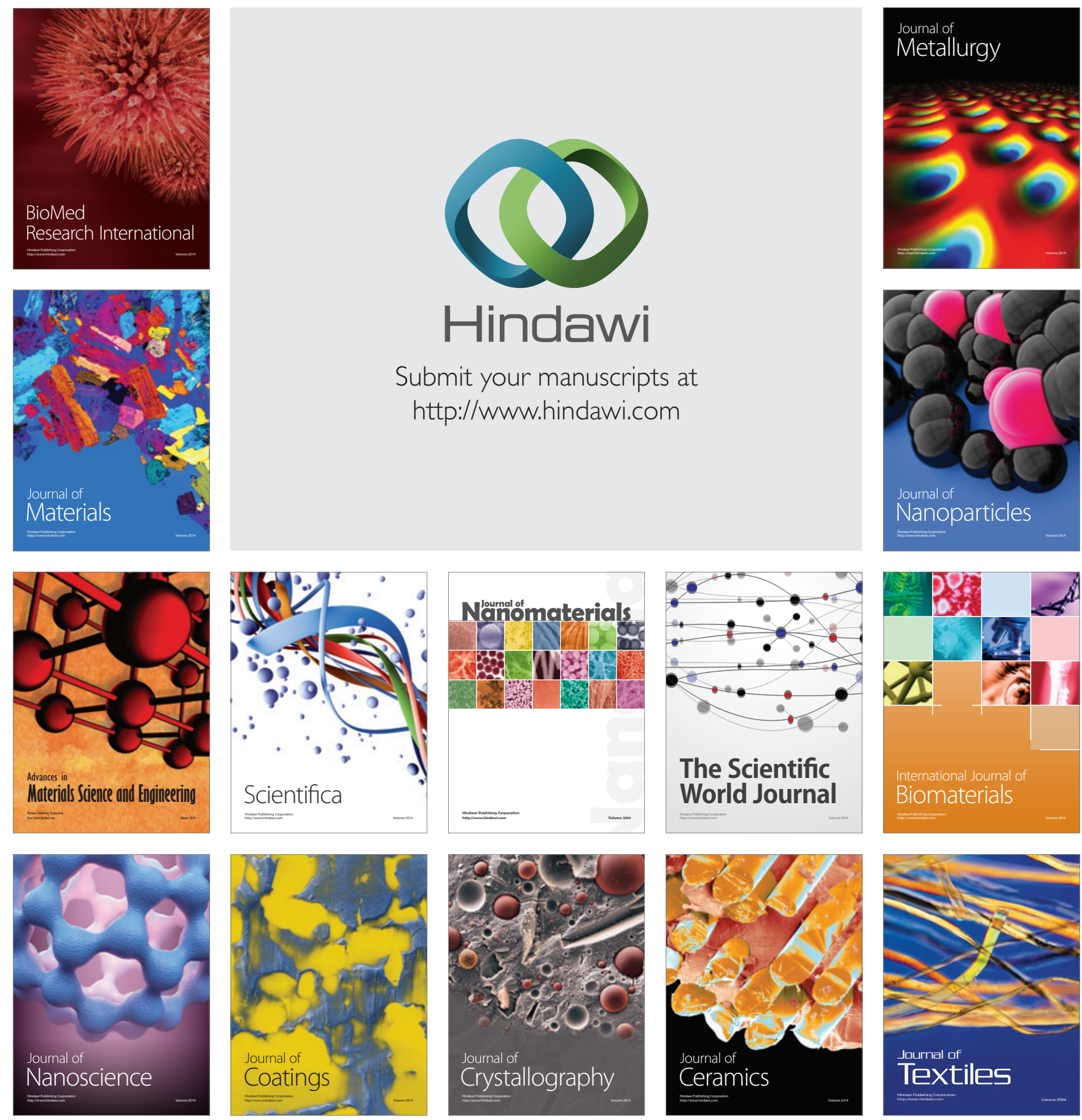